\title{
Development of the Artistic Supervision Model Scale (ASMS) *
}

\author{
Saduman Kapusuzoglu ${ }^{1}$, Umit Dilekci ${ }^{2, *}$ \\ ${ }^{1}$ Faculty of Education, Hacettepe University, Turkey \\ ${ }^{2}$ Institute of Education Sciences, Abant Izzet Baysal University, Turkey
}

Copyright $\bigcirc 2017$ by authors, all rights reserved. Authors agree that this article remains permanently open access under the terms of the Creative Commons Attribution License 4.0 International License

\begin{abstract}
The purpose of the study is to develop the Artistic Supervision Model Scale in accordance with the perception of inspectors and the elementary and secondary school teachers on artistic supervision. The lack of a measuring instrument related to the model of artistic supervision in the field of literature reveals the necessity of such study. 290 teachers working in 14 public elementary and secondary schools in Bolu province and 179 educational inspectors working in 17 provinces participated in the study. In order to verify the scale, exploratory factor analysis and confirmatory factor analysis were conducted. For the reliability of the scale, internal consistency and item analysis were calculated. SPSS 18.00 and Lisrel 8.7 package programs were used for the data analysis. The analysis of the data revealed that it is a reliable scale made up of four dimensions and has a very good adaptation value. The dimensions involved in the scale are called as philosophy of artistic inspection, teaching as an art, assessment activities for artistic approach, and educational specialty task for the inspector.
\end{abstract}

Keywords Supervision, Artistic Supervision, Teacher, Educational Inspector

\section{Introduction}

\subsection{Educational Supervision}

Supervision, which is one of the basic elements of the education systems, is an important process to maintain educational activities in an effective and efficient way. Excluding the supervision in every situation where education is emphasized will leave the education unsupported as supervision comes at the forefront of the process that guides and leads the educators like a guide [1]. Lack of supervision in organizations leads to stability, hiddenness, disorganization and loss of power [19]. In order to maintain the existence of the education system properly, different definitions have been made by many authors concerned with such a large audit, and in these definitions, the authors have considered the supervision with different perspectives. Supervision, according to Aydin [5] is the process of understanding whether organizational actions are convenient with accepted principles and rules of accepted objectives. Bursalıglu defines [9] it as a method of controlling behaviour on behalf of the common good. In addition to these, Caspi and Reid mention another side and state [11] that supervision is conducted by the administrative force to observe someone else's work, direct the effort, put forward and ultimately ensure competence. Janssens and Van Amelsvoort [17] stated that supervision determines the level of satisfaction of parents and students' needs in educational institutions, and to develop the quality of education by reporting according to local and national performance criteria. Besides, Lunenburg and Ornstein [21] defined the process of observing and correcting schools as a process to prevent them from deviating from their goals.

In the historical process, with the developments in management theories, the meaning and goal of supervision have changed. There has been a shift from bureaucratic supervision based on control to democratic supervision, which aims to improve the teaching of teachers. Eventually, understanding of supervision has shifted from control to participation and from evaluation to support [26]. Supervising does not convey the personal experiences of those who are supposed to be equipped with knowledge of superior qualities, based on the control of teacher behaviours as in the past, or because of the management position [25]. Supervising is now regarded as a function that focuses on development rather than supervision. From this point of view, the supervision and development of education in particular has become one of the most necessary issues in reaching the objectives of the educational site [4]. Along with the new management conception indicating the importance of the human subject in organizations, the supervising classical approach gave place to contemporary supervision approaches with a process-oriented structure based on 
teacher self-examination [20]. Today, education supervision has become a foreseen process to be implemented with modern education supervision approaches, process development, guidance and professional assistance [22].

\subsection{Contemporary Educational Supervision and Approaches}

New approaches have emerged in the supervision system with developments and changes. These new approaches are expressed as modern educational supervision approaches that emphasize participatory, collaborative, research and evaluation-based supervision practices in contemporary concept and aims to enable them to acquaint with more knowledge about the practices of inspectors and teachers and as a process that help to use their knowledge and skills in the best way for schools and parents [6]. The leading approaches can be listed as scientific, instructional, clinical, developmental, differentiated, artistic supervision [4]. In the studies on educational supervision, it is seen that applications related to scientific, clinical and instructional supervision are focused, and as a result, there is more place for the applications of these supervisory approaches. However, differentiated, developmental and artistic supervisions have been less emphasized and consequently there is less emphasis for implementation of these approaches [29].

In general terms, scientific supervision is a classical type of supervision based on controlling and reporting, constrained by identification of the problems, and under the influence of classical management theories. There is an understanding between the inspector and teacher that does not go beyond the subordinating relations [7]. Instructional supervision is the process of improving education, training leadership and facilitating changes in a comprehensive manner [14]. The basic concepts that are considered and fore-grounded in the instructional supervision process can be listed as development of teaching, classroom management discipline, communication, curriculum, group relationship, observation, problem solving, decision making, research and motivation [Glickman 1990; Glickman, Gordon and Ross-Gordon, 2001, Unruh, 1997, Pajak, 1990, Tunison, 2005; cited in 23]. Clinical supervision is to increase the students' success by improving the behaviour of the teacher in the teaching process by observing the teacher in an adequate classroom environment in order to improve the efficiency of the teaching process [16]. Developmental supervision is a supervision model in which the experimenter analyzes the developmental level of the teachers, applies the supervision activity with these analyses, and removes the supervision from a fearful process [4]. Differentiated supervision seeks the increase of learners' learning by taking professional development as the focal point in the supervision of teacher and bringing the teacher to the best point on the existing potential axis by taking into account the needs of teacher under the supervision of the teachers; presenting different professional development approaches according to the needs of teachers, and with the participation of teachers it provides feedback from different sources such as teachers, administrators, inspectors, colleagues and students [15].

\subsection{Artistic Supervision as a Contemporary Educational Supervision Approach}

It is an unquestionable fact that education is an art. As an artist whose most significant peculiarity is her/his authenticity. In term of realizing the objectives of the education each teacher's education, applications are unique and include individual differences [30].

Artistic supervision, which is one of the contemporary supervision models that takes its place in literature recently, is based on inspector's knowledge, skill, comprehension and sensitivity in assessment and inspector's competence in expressing the observation to the teacher, who is one of the basic elements of the teaching process concerning the emerging important details in the classroom environment [32]. Beyond the common, rigid, continuous inspection applications it can be defined as an approach that views the kind behavior to the teacher as significant and focuses on teachers as the ones who make detailed analysis and evaluation of the data in the classroom applications, and in terms of the teachers' characteristics that differentiates the observed teachers from their colleagues. Instead of rigid, hierarchical perspective, it is realized with communication, shared effort, professional force and responsibility for the common goals $[24,29]$.

It can be said that the point of view of artistic approach towards teaching is influential in the emergence of the concept of artistic supervision. As Eisner (1983) points out, teaching is an art, and it does not always take place as previously designed. On the contrary, it depends on the circumstances. The precise rules about how teachers should teach lock up deactivate the teachers [Hopkins and Moore, 1993; cited in 4]. Because teachers' teaching style, the way they communicate with students, and their ability to use teaching methods and techniques is quite different, it can be said that these differences in teacher's style and communication skills are included in the focal points of the artistic supervision approach. In the artistic supervision approach, it helps to develop the skills related to language, speech, appealing and expressions used by teachers [32].

Artistic supervision approach aims at the mutual perception of the teaching-learning process and the evaluation of the qualities and distinctive features of the parts that constitute it apart from the whole process. In order to accomplish these goals, the inspector should be able to answer questions such as "What makes this teacher special?", "What are the features that add value to this teaching?", "How can I strengthen these aspects as an inspector?" [24]. In addition, the inspector should act in accordance with the following principles when observing [Sharp, 1990; cited in 32]: 
- The observer should concentrate on the behaviour of the student.

- Observational dimension should be limited to a small number of student groups.

- The natural pattern of the class should not be intervened.

- Inspectors should take full, clear and accurate notes in classroom observations.

- Inspectors should conduct a detailed analysis of the data recorded during the observation

- Teachers should provide feedback to the inspector. The inspector should give the teacher the most accurate and objective information.

Eisner's artistic supervision approach consists of four basic elements [Pajak, 1993; cited in 4]:i. Inspectors should have the ability to grasp and see important aspects of the situation they observe. In other words, they must be experts in class life. ii. Inspectors should be able to define what they see, catch the aims of supervision, and they must have the ability to express what they see in impressive language that. iii. Inspectors should be able to comment on appropriate theories, models and concepts that can explain the dynamics of the class. $i v$. There are an evaluation and a review process of the observations and interpretations at the last stage of the model.

Eisner believes that quantitative measurement tools are not efficient and useful enough for evaluation. He gives importance to criticism as an alternative to quantitative measurement tools. From this point of view, criticism is the use of a language that shows the sensitivity and appreciation of the inspector for the understanding and recording of the finer details, complexity, and significance of what is happening in the classroom environment. The inspector looks for the presence of visual, auditory and kinaesthetic texts rather than obedience [Pajak, 1993; cited in 4]. If inspectors are approached critically or artistically, the teachers may be more likely to help them communicate their artistic competences and their educational skills in the teaching process [18].

Artistic supervision, a contemporary model of control, has some important aspects that arise from this new point of view. Eisner summarizes the important aspects of the artistic supervision approach in eight articles. That is, artistic supervision [cited in 24]:

1. It is necessary to take into consideration not only the appearance but also the hidden features of the events that appear.

2. Inspectors need to have a high level of educational expertise to enable them to see important details.

3. The teacher should make special contributions to the development of his or her students in terms of education as much as their general and common contributions.

4. In order to understand the importance of the events that take place in the classroom environment, it is necessary to observe the teaching-learning process within a certain period of time and pay attention to the class life process.

5. Mutual trust and communication between the inspector and the teacher should be demanded and ultimately harmonized.

6. Inspectors need to have the ability to use the language well in order to be able to communicate and explain their observations accurately.

7. Inspectors should have the ability to interpret the meaning of events and appreciate their educational values.

8. Since the educational level of the teacher is perceived and interpreted by the inspector, it is necessary to come to an agreement that the inspector's strong aspects, experiences and feelings are the basic tools in the process of supervision.

\subsection{Purpose of the Research}

When the literature is examined, it is seen that there are few researches and measurement tools related to the artistic supervision approach. In this sense, it is aimed to obtain a scale that measures the artistic supervisory behaviours of the inspectors and provides validity and credibility by examining the judgments related to artistic supervision by conducting screening of the texts in accordance with these reasons.

\section{Method}

\subsection{Universe and Sampling}

Based on the general screening model, the participants of this research is composed of 43 public elementary and secondary schools in the central province of Bolu, 1115 class and branch teachers working in these schools, and 706 educational inspectors working in 17 provinces selected randomly. Related to the sample of the survey; 14 public elementary and secondary schools were selected and 540 teachers determined randomly considering the number of teachers in schools. Repetitive markers, uncompleted scale, irrelevant answer to resembling items and inconvenient responses were not included in the study. Eventually 469 participants were reached within the scope of the research. Of these participants, 179 were educational inspectors (38.2\%), 136 were classroom teachers $(29.0 \%)$ and 154 were branch teachers $(32.8 \%)$. Tavsancil [28] stated that, in the Likert type scale development study, the research group should be operated on at least five times the number of items in the scale. For this reason, it has been noted that the sample forming the research group is at least five times more than the number of items in the scale.

\subsection{Data Collection Tool}

During the process of developing the Artistic Supervision Model Scale (ASMS), theoretical knowledge and research related to the artistic supervision approach was examined and a 66-item inventory was established based on these 
examinations. Experts were consulted regarding the scale items on the draft data collection tool to determine their suitability. For this purpose, the considerations of artistic supervision model scale were presented to the evaluation of the two experts in the field of educational sciences. The opinions of the experts of the educational sciences were taken out from the scale of 8 items and the opinions of the Turkish language experts about whether or not the items were understandable were taken. After the necessary corrections were made, artistic supervision scale with 58 items draft scale was constituted. A response section consisting of five options was created for each item on the draft scale being arranged and the options one to five were arranged. Options and points corresponding to the items; the last form is given to the scale by forming none (1), little (2), medium (3), to a great extent (4), completely (5). Detailed and comprehensive analyses of validity and reliability studies were conducted and the results of these analyses were extensively included in the findings section.

\subsection{Operation}

The scale, which was organized as Likert type, was distributed to 706 inspectors within 540 classes and branch teachers in the study group and returned from 290 teachers and 179 inspectors. After the material error checks were made in the data, analysis was done by using SPSS 18.00 and Lisrel 8.7 package programs. For validity construction, explanatory factor analysis, confirmatory factor analysis and internal consistency coefficient analysis have been performed for the reliability of the study.

\section{Findings}

\subsection{Exploratory Factor Analysis}

Preliminary application was made in order to determine the factor structure of the artistic supervision model scale (ASMS). From this preliminary application, exploratory factor analysis was performed with collected data to determine how many factors were included in the scale, and maximum likelihood method and varimax rotation process were applied for this purpose. The factor structure resulting from this process is shown in the table 1.

As shown in Table 1, as a result of the exploratory factor analysis, it is found that the scale consists of four factors. These are 1. Philosophy (philosophy of artistic inspection, seventeen items / 1-17), 2. Teaching (teaching as an art, ten items /18-27), 3. Activity (assessment activities for artistic approach, twenty one items / 28-48) and 4. Specialization (educational specialty task for the inspector, ten items / 49-58). As a result, the artistic supervision model scale (ASMS) consists of 58 items and 4 dimensions emerged.

Table 1. Results of Exploratory Factor Analysis of the Artistic Supervision

\begin{tabular}{|c|c|c|c|c|c|c|c|c|c|c|c|c|c|c|}
\hline \multirow{2}{*}{$\begin{array}{c}\text { Item } \\
\text { Number }\end{array}$} & \multicolumn{4}{|c|}{ Factor Load Ratings } & \multirow{2}{*}{$\begin{array}{c}\text { Item } \\
\text { Number }\end{array}$} & \multicolumn{4}{|c|}{ Factor Load Ratings } & \multirow{2}{*}{$\begin{array}{l}\text { Item } \\
\text { Number }\end{array}$} & \multicolumn{4}{|c|}{ Factor Load Ratings } \\
\hline & $\begin{array}{c}\text { Factor } \\
1\end{array}$ & $\begin{array}{c}\text { Factor } \\
2\end{array}$ & $\begin{array}{c}\text { Factor } \\
3\end{array}$ & $\begin{array}{c}\text { Factor } \\
4\end{array}$ & & $\begin{array}{c}\text { Factor } \\
1\end{array}$ & $\begin{array}{c}\text { Factor } \\
2\end{array}$ & $\begin{array}{c}\text { Factor } \\
3\end{array}$ & $\begin{array}{c}\text { Factor } \\
4\end{array}$ & & $\begin{array}{c}\text { Factor } \\
1\end{array}$ & $\begin{array}{c}\text { Factor } \\
2\end{array}$ & $\begin{array}{c}\text { Factor } \\
3\end{array}$ & $\begin{array}{c}\text { Factor } \\
4\end{array}$ \\
\hline 1 & 887, & & & & 21 & & 824 & & & 41 & & & ,392 & \\
\hline 2 & 868 & & & & 22 & & 811 & & & 42 & & & ,380 & \\
\hline 3 & 824 & & & & 23 & & ,783 & & & 43 & & & ,378 & \\
\hline 4 & 809 & & & & 24 & & ,706 & & & 44 & & & ,345 & \\
\hline 5 & 706 & & & & 25 & & 687 & & & 45 & & & ,343 & \\
\hline 6 & 677 & & & & 26 & & ,639 & & & 46 & & & ,339 & \\
\hline 7 & 649, & & & & 27 & & ,616 & & & 47 & & & ,314 & \\
\hline 8 & 633 & & & & 28 & & & 616 & & 48 & & & ,302 & \\
\hline 9 & ,580 & & & & 29 & & & 600, & & 49 & & & & 902 \\
\hline 10 & ,574 & & & & 30 & & & ,595 & & 50 & & & & 843 \\
\hline 11 & ,558 & & & & 31 & & & ,564 & & 51 & & & & ,783 \\
\hline 12 & ,543 & & & & 32 & & & ,562 & & 52 & & & & ,576 \\
\hline 13 & ,541 & & & & 33 & & & 481 & & 53 & & & & ,483 \\
\hline 14 & ,499 & & & & 34 & & & 477 & & 54 & & & & ,475 \\
\hline 15 & ,495 & & & & 35 & & & 473 & & 55 & & & & ,455 \\
\hline 16 & ,478 & & & & 36 & & & 468 & & 56 & & & & ,430 \\
\hline 17 & ,443 & & & & 37 & & & 462 & & 57 & & & & ,423 \\
\hline 18 & & ,857 & & & 38 & & & ,443 & & 58 & & & & ,390 \\
\hline 19 & & 843 & & & 39 & & & ,423 & & & & & & \\
\hline 20 & &, 830 & & & 40 & & & ,400 & & & & & & \\
\hline
\end{tabular}




\subsection{Confirmatory Factor Analysis}

For the validity construction, factor analysis was carried out to confirm the scale. Confirmatory factor analysis (CFA) seeks to reconcile observable factors with actual data. Prescribed factors are tested by confirmatory factor analysis. CFA is a necessary application for testing theoretical constructs. A number of compliance indices can be looked at in confirmatory factor analysis. Confirmatory factor analysis is a test technique used to test the validity of the structure [10, $12,27]$. Confirmatory factor analysis was performed using the Lisrel 8.7 program to assess the validity of this four-factor construct resulting from exploratory factor analysis. By this way, the representation power of both materials and the relationship of the sub-dimensions to each other are shown in Fig.1.
Figure 1 shows the four-factor model of the artistic supervision model scale (ASMS) and the relationships between the factors in the model and the factors involved in that factor. The first value to be examined here is the "p" value. This gives information about the difference $\left(X^{2}\right.$ value) between the expected covariance matrix and the observed covariance matrices. It was observed that the coefficient of correlation calculated between factors and items was higher than 0.30 in all items except item 54 and all structure-indicator relations were found significant at 0.01 level. Here, $X^{2}$ (Chi-Square) value is evaluated by rating with the degree of freedom (sd). $X^{2}=372.58$ and $\mathrm{sd}=191$. When these values are compared to each other, it is seen that $X^{2} / s d$ ratio is $1.95(372.58 / 191=1.95)$. A value of less than 3 indicates a good fit [12].

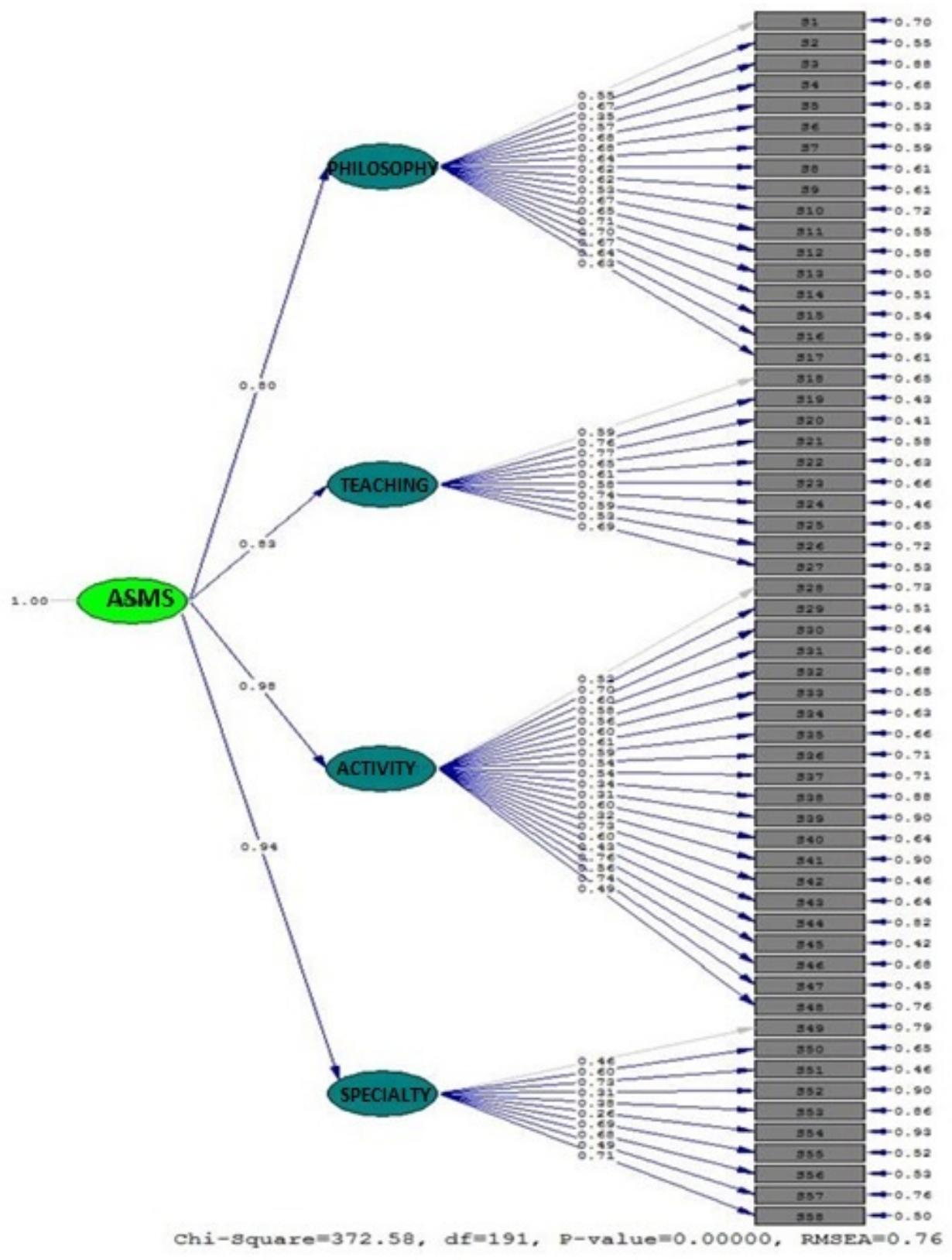

Figure 1. Confirmatory Factor Analysis Results of the Artistic Supervision Model Scale 
As can be seen in Figure 2, the existence of a relationship among philosophy (philosophy of artistic inspection), teaching (teaching as an art), activity (assessment activities for artistic approach) and specialty (educational specialty task for the inspector) dimensions constitutes the artistic supervision model scale.

Parameter values and related statistics for observed variables are presented in Table 2 .

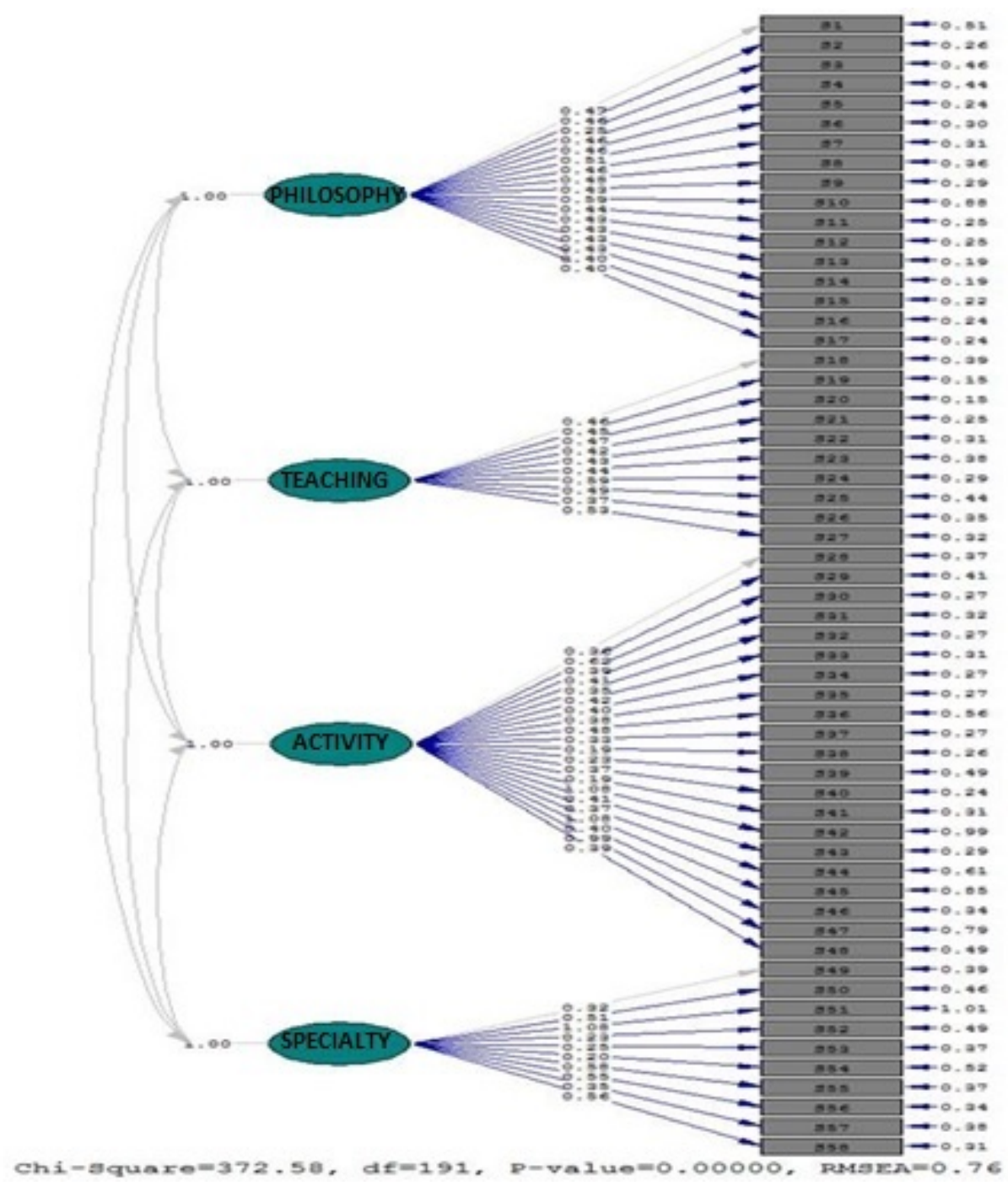

Figure 2. The Result of Relationship Between The Items of Artistic Supervision Modelling Scale

Table 2. Parameter Values and Related Statistics for Observed Variables

\begin{tabular}{|c|c|c|}
\hline Philosophy $=0.80 *$ ASMS & Error Variance $=0.35$ & $R^{2}=0.65$ \\
\hline$(0.071)$ & $(0.061)$ & $R^{2}=0.69$ \\
\hline 11.25 & 5.83 & $R^{2}=0.97$ \\
\hline Teaching $=0.83 *$ ASMS & Error Variance $=0.31$ & \\
\hline$(0.068)$ & $(0.051)$ & $R^{2}=0.88$ \\
\hline 12.30 & 6.05 & \\
\hline Activity $=0.98 *$ ASMS & Error Variance $=0.035$ & \\
\hline$(0.085)$ & $(0.021)$ & \\
\hline 11.54 & 1.65 & \\
\hline Specialty $=0.94 *$ ASMS & Error Variance $=0.12$ & \\
\hline$(0.095)$ & $(0.034)$ & \\
\hline 9.89 & 3.40 & \\
\hline
\end{tabular}


When we analyze at the values in Table 2, the standard error (in parentheses) and the $t$-values below these values are reported in the rows for each variable. One of the most important of these values is $R^{2}$ value that gives us the variance explained in each variant [27]. When we look at these values, artistic supervision model factor variability is most explained in Activity (0.97) and least in Philosophy $(0.65)$.

Table 3 shows the values of goodness of fit for the artistic supervision model.

Table 3. Values of Goodness of Fit for the Artistic Supervision Model

\begin{tabular}{|l|l|}
\hline Degrees of Freedom & 191 \\
\hline Minimum Fit Function Chi-Square & $449.59(\mathrm{P}=0.0)$ \\
\hline $\begin{array}{l}\text { Normal Theory Weighted Least Squares } \\
\text { Chi-Square }\end{array}$ & $\mathbf{3 7 2 . 5 8}$ (P = 0.0) \\
\hline Estimated Non-centrality Parameter (NCP) & 81.58 \\
\hline 90 Percent Confidence Interval for NCP & $(45.88 ; 154.23)$ \\
\hline Minimum Fit Function Value & 0.19 \\
\hline Population Discrepancy Function Value (F0) & 0.17 \\
\hline 90 Percent Confidence Interval for F0 & $(0.39 ; 0.47)$ \\
\hline $\begin{array}{l}\text { Root Mean Square Error of Approximation } \\
\text { (RMSEA) }\end{array}$ & $\mathbf{0 . 0 3 2}$ \\
\hline 90 Percent Confidence Interval for RMSEA & $(0.021 ; 0.060)$ \\
\hline $\begin{array}{l}\text { P-Value for Test of Close Fit (RMSEA }< \\
\text { 0.05) }\end{array}$ & 0.032 \\
\hline Expected Cross-Validation Index (ECVI) & 0.69 \\
\hline 90 Percent Confidence Interval for ECVI & $(0.31 ; 0.88)$ \\
\hline ECVI for Saturated Model & 0.41 \\
\hline ECVI for Independence Model & 4.26 \\
\hline $\begin{array}{l}\text { Chi-Square for Independence Model with 153 } \\
\text { Degrees of Freedom }\end{array}$ & 1192.89 \\
\hline Independence AIC & $\mathbf{2 3 0 8 . 8 9}$ \\
\hline Model AIC & $\mathbf{3 1 2 . 5 8}$ \\
\hline Saturated AIC & 422.00 \\
\hline Independence CAIC & $\mathbf{2 6 0 7 . 6 2}$ \\
\hline Model CAIC & $\mathbf{4 3 0 . 6 5}$ \\
\hline Saturated CAIC & 734.68 \\
\hline Normed Fit Index (NFI) & 0.51 \\
\hline Non-Normed Fit Index (NNFI) & 0.47 \\
\hline Parsimony Normed Fit Index (PNFI) & 0.53 \\
\hline Comparative Fit Index (CFI) & $\mathbf{0 . 8 5}$ \\
\hline Incremental Fit Index (IFI) & 0.55 \\
\hline Relative Fit Index (RFI) & 0.49 \\
\hline Critical N (CN) & 286.44 \\
\hline Root Mean Square Residual (RMR) & 0.069 \\
\hline Standardized RMR & 0.49 \\
\hline Goodness of Fit Index (GFI) & \\
\hline Parsimony Goodness of Fit Index (PGFI) & 0.53 \\
\hline
\end{tabular}

In order for a model to be acceptable, the criteria of "goodness of fit" are considered [31]. The most commonly used fit indexes for the confirmatory factor analysis were Root Mean Square Error of Approximation (RMSEA), Goodness of Fit Index (GFI), Comparatice Fit Index (CFI), Normed Fit Index (NFI), Non Normed Fit Index (NNFI), and Adjusted Goodness of Fit Index (AGFI). As a result of this research, compliance with GFI, AGFI, NFI, NNFI and CFI fit indices above .90 is considered as a good fit. The RMSEA value as .05 and below is "excellent" and .80 and below is acceptable [27]. When we examine the values in Table 3, we can see that the model produces very good values in terms of all goodness-of-fit criteria and can be accepted easily. Likewise, RMSEA (0.032), CFI (0.85) and GFI (0.90) also show good agreement as seen on the table. In addition, we can see that the AIC (312.58) and CAIC (430.65) values are lower than the independence model (2308.89 and 2607.62) and the saturated model (422.00 and 734.68 , respectively). These values show a great goodness of fit in real terms.

\subsection{Reliability}

The reliability of the data collection tool has been tested. According to Altunisik, Coskun, Bayraktaroglu, Yildirim [2]; "The time interval between two measurements is between two and four weeks." With this information, the scale was applied to the subject group of the study for fifteen days. There was no significant difference between the initial application and the final application in the pre-application study results ( $p>0,05)$. Cronbach's Alpha method was used to measure internal consistency, and each dimension was examined for its internal consistency. According to the reliability analysis of the questionnaire consisting of four sub-dimensions; the first dimension is .90 , the second dimension is .87 , the third dimension is .90 , and the fourth dimension is .80 . In the light of these results, it is possible to say that are reliable. Because "Alpha value is between 0 and 1 , it is desirable that an acceptable value is at least 0.7" [2].

\section{Discussion and Conclusion}

It is possible to state that there is a lack of studies and the measurement instruments of the artistic supervision which is one of the modern supervisions approaches. However, especially in recent years, the model of artistic supervision has attracted the attention of researchers and has become a subject of research. Seckin [24]; Yilmaz [32]; Bostanci, Sanlı Bulut and Ozbey [8]; Deaver and Shiftleft [13]; Ugurlu, Mermer and Ertas [30]; Ugurlu [29]; Yilmaz and Ozdem [33]; Argon, Ismetoglu and Iseri [3] have contributed to this field with theoretical and research-based studies.

In the development of the Artistic Supervision Model Scale (ASMS), scope and structure validity studies were included for validity studies. For this aim; explanatory factor analysis and confirmatory factor analysis were performed. 
For the reliability studies, Cronbach's Alpha values, corrected item total correlations, and Cronbach's Alpha values when subtracted were examined.

An exploratory factor analysis was performed to determine how many factors were included in the scale. For this purpose, varimax rotation was performed using the maximum likelihood method. As a result of this process, it was determined that the scale consists of four dimensions and these dimensions as philosophy of artistic inspection, teaching as an art, assessment activities for artistic approach and educational specialty task for the inspector. In Bostanci, Sanlı Bulut and Ozbey's [8] studies, the factors are classroom observation, human relations, teacher development, educational criticism and evaluation. In Ugurlu's [29] studies, the factors involved in the scale were inspector qualifications, inspector attitude, instructional dimension and human relations. In Ugurlu, Mermer and Ertas' [30] studies, they are the quality of the inspector, inspector attitude, human relations and instructional.

For the validity construction, factor analysis was carried out to confirm the scale. It was observed that the coefficient of correlation calculated between the factors and the items was higher than 0.30 in all items except for item 54, and all structure-indicator relations were found significantly at a 0.01 level. We can see that the model produces quite good values in terms of all the criteria of goodness of fit and can easily be accepted in this state. Likewise, RMSEA (0.032), CFI (0.85) and GFI (0.90) values also show good agreement. In addition, we can see that the AIC (312.58) and CAIC (430.65) values are lower than the independence model (2308.89 and 2607.62) and the saturated model (422.00 and 734.68 , respectively). These values show a great goodness of fit in real terms.

For the reliability of the study, each dimension is examined in its internal consistency and the results obtained (1.dimension .90, 2.dimension .87, 3.dimension .90, 4.dimension .80) indicate that the scale is reliable. Based on the research findings, it can be said that the Artistic Supervision Model Scale (ASMS) is a valid and reliable scale consisting of 4 dimensions and 58 items.

It can be concluded that the Artistic Supervision Model Scale can be used for the research aim because of the reliability and validity result and at the same time it is suggested to develop new scales with different dimensions.

\section{Note}

${ }^{*}$ This article is based on the master thesis completed by Umit DILEKCI in consultation with Assoc. Prof. Dr. Saduman KAPUSUZOGLU (An analysis of the adoptability of artistic supervision model at public primary schools).

\section{REFERENCES}

[1] Altınışı, S. ve Binbir, Ü. (2015). Son onbeş yılda Türkiye'de eğitim denetimine ilișkin yapılan tezlerin analizi. Prof. Dr. Mustafa AYDIN'a Armağan: eğitim ve toplum yazıları. Editör: Mualla BİLGIN AKSU, Hasan ŞİMŞEK (1.Baskı). Ankara: Gazi Kitabevi.

[2] Altunışık, R., Coşkun, R., Bayraktaroğlu, S. ve Yıldırım, E. (2005). Sosyal bilimlerde araştırma yöntemleri SPSS uygulamaları. Sakarya Kitapevi.

[3] Argon, T., İsmetoğlu, M. ve İşeri, B. (2014) . İlkokullarda sanatsal denetim ve öğretmen motivasyonu üzerine öğretmen görüşleri. Ĕ̆itim ve Ö̆gretim Araştırmaları Dergisi. 3, 2, 30.

[4] Aydın, İ. (2008). Öğretimde denetim: durum saptama, değerlendirme ve geliştirme (2.Bask1). Ankara: Pegem Akademi Yayıncılık.

[5] Aydın, M. (2014). Çă̆daş eğitim denetimi (6.bask1). Ankara: Gazi Kitabevi.

[6] Balci, A., Demirkasimoglu, N., Erdogan, C. \& Akin, U. (2011). Turkish teachers' and supervisors' metaphorical perceptions about supervisors. International Research Journals, 2(10), 1602-1610.

[7] Başar, H. (2000). Eğitim denetçisi. Ankara: Pegem Akademi Yayıncilık.

[8] Bostancı A. B., Şanlı Bulut, M. ve Özbey H. (2011). Öğretmen denetiminde sanatsal denetim yaklaşımının uygulanmasına yönelik öğretmen ve denetmen görüşleri. Mehmet Akif Ersoy Üniversitesi Eğitim Fakültesi Dergisi, 22,238-254.

[9] Bursalığlu, Z. (2005). Okul yönetiminde yeni yapr ve davranış (13. Bask1). Ankara: Pegem Akademi Yayıncılık.

[10] Büyüköztürk, Ş. (2010). Veri analizi el kitabı (12. Basım). Ankara: Pegem Akademi Yayıncılık.

[11] Caspi, J. \& Reid, W. J. (2002). Educational Supervision in Social Work - a Task Centered Model for Field Instruction and Staff Development. New York: Columbia University Press.

[12] Çokluk, Ö., Şekercioğlu, G. ve Büyüköztürk, Ş. (2012). Sosyal bilimler için çok değişkenli istatistik SPSS ve LISREL uygulamaları. Ankara: Pegem Akademi Yayıncıl1k.

[13] Deaver, S. P. \& Shiftleft, C. (2012). Art-based supervision techniques, The Clinical Supervisor, 30, 257-276.

[14] Glanz, J. \& Behar-Horenstein, L. S. (2000). Paradigm debates in curriculum and supervision: Modern and postmodern perspectives. Westport, CT: Greenwood Publishing.

[15] İlğan, A. (2008). İlköğretim müfettişleri ve öğretmenlerinin farklılaştırılmıș denetim modelini benimseme ve uygulanabilir bulma düzeyleri. Kuram ve Uygulamada Ĕ̈itim Yönetimi. 55, $389-422$.

[16] İlğan A. ve Kıranlı S. (2007). Öğretmenlerin sınıf içi etkinliklerinin denetlenmesinde klinik denetim modeli. Ankara Üniversitesi Ĕ̆itim Bilimleri Fakültesi Dergisi, 40 (2), 151-177.

[17] Janssens, F. J. K. \& Van Amelsvoort, G. H. (2008). School self-evaluationsand school inspections in europe: An exploratory study. Studies in Educational Evaluation, 34, $15-23$.

[18] Kelehar, Z. (2008). Instructional leadership, connoisseurship and critique: Using an arts-based approach to extend conversations about teaching. Int. J. Leadership in Educatıon, 11 (3), 239-256. 
[19] Kimbrough, R. B. \& Burkett, C. W. (1990). The principalship: concepts and practices. Englewood Cliffs, NJ: Prentice-Hall.

[20] Kondakçı, Y. ve Zayim, M. (2013). Eğitim yönetiminde kuram ve uygulama. (Editör: S. Özdemir). Ankara: Pegem Akademi Yayınları.

[21] Lunenburg, F. C. \& Ornstein, A. C. (2011). Educational administration: concepts and practices (6th ed.). Belmont, CA: Thomson Wadsworth Publishing.

[22] Memduhoglu, H. B., Mazlum, M. M. \& Acar, M. (2015). Teachers' perception about education supervisors' communication skills. Kastamonu Education Journal, 23 (4).

[23] Memduhoğlu, H. B. ve Zengin, M. (2012). Çağdaş eğitim denetimi modeli olarak öğretimsel denetimin Türk eğitim sisteminde uygulanabilirliği. Journal of Theoretical Educational Science / Kuramsal Eğitimbilim Dergisi, 5 (1).

[24] Seçkin, N. (1998). Denetime yeni bir yaklaşım: sanatsal denetim. Türkiye'de eğitim yönetimi. Prof. Dr. Ziya Bursalıoğlu'na armağan. (Ed: H. Taymaz ve M. Hesapçıŏlu). İstanbul: Kültür Koleji Eğitim Vakfi yayınları.

[25] Sergiovanni, T. J. \& Starrat, R. J. (2002). Supervision: a redefinition (7.th ed.). New York: McGraw Hill.

[26] Sullivan, S. \& Glanz, J. (2000). Supervision that improves teaching: strategies and techniques (2.th ed.). California: Corwin Press.
[27] Simșek, Ö. F. (2007). Yapısal eșitlik modellemesine giriș: temel ilkeler ve LISREL uygulamalart. Ankara: Ekinoks Yayıncilik.

[28] Tavşancıl, E. (2002). Tutumların ölçülmesi ve SPSS ile veri analizi. Ankara: Nobel Yayıncilık.

[29] Uğurlu, C. T. (2013). Sanatsal denetim ölçeği geçerlik ve güvenirlik çalışması. Kuram ve Uygulamada Eğitim Yönetimi [Educational Administration: Theory and Practice], 19 (1), 119-134.

[30] Uğurlu, C. T., Mermer, S. ve Ertaş, B. (2013). Denetimlerin sanatsal denetim anlayışına uygunluğuna ilişkin öğretmen görüşleri. İlköğretim Online, 12(2), 597 - 613.

[31] Uzun, N. B., Gelbal, S. ve Öğretmen, T. (2010). Tımss-R fen başarısı ve duyuşsal özellikler arasındaki ilişkinin modellenmesi ve modelin cinsiyetler bakımindan karşılaştırılması. Kastamonu Eğitim Dergisi, 18 (2), 531-544.

[32] Y1lmaz, K. (2004). Sanatsal denetim. Kuram ve Uygulamada Eğitim Yönetimi, 38, 292-311.

[33] Y1lmaz, K. ve Özdem, G. (2014). Eğitim denetmenlerinin sanatsal denetim uygulamaları hakkında öğretmen görüşleri. Prof. Dr. Haydar TAYMAZ Armăgan Kitabı: Ĕ̆itim Yönetimi, Denetimi ve Politikası Yazıları. Editör: İnayet AYDIN, Kürşat YILMAZ. (1.Bask1) Ankara: Pegem Akademi. 